\title{
The role of melanocortin-3 and -4 receptor in regulating appetite, energy homeostasis and neuroendocrine function in the pig
}

\author{
C R Barb, A S Robertson ${ }^{1}$, J B Barrett, R R Kraeling and \\ K L Houseknecht ${ }^{1}$ \\ USDA-ARS, Russell Research Center, PO Box 5677, Athens, Georgia 30604, USA \\ ${ }^{1}$ Pfizer Global Research and Development, Pfizer, Inc., Groton, Connecticut 06340, USA \\ (Requests for offprints should be addressed to C R Barb; Email: rbarb@saa.ars.usda.gov)
}

\begin{abstract}
A recently discovered class of receptors, melanocortin-3 and -4 receptor (MC3/4-R), are located within the brain and modulate feed intake in rodents. Stimulation of the receptor (agonist) inhibits feed intake whereas blockade (antagonist) of the receptor increases intake. Our knowledge of factors regulating voluntary feed intake in humans and domestic animals is very limited. i.c.v. administration of an MC3/4-R agonist, NDP-MSH, suppressed $(P<0 \cdot 05)$ feed intake compared with controls at 12, 24, 48 and $72 \mathrm{~h}$ after treatment in growing pigs. Fed pigs were more responsive to the $\mathrm{MC} 3 / 4-\mathrm{R}$ agonist then fasted animals. However, i.c.v. treatment with $\mathrm{MC} 3 / 4-\mathrm{R}$ antagonist, SHU9119, failed to stimulate intake. The failure of $\mathrm{MC} 3 / 4-\mathrm{R}$ antagonist to stimulate feed intake suggests involvement of other brain hormone(s) which antagonize the action of SHU9119 at the MC3/4-R, blocking its stimulatory effect on intake. Treatment with NDP-MSH or SHU9119, across a wide dose range, failed to affect $\mathrm{LH}$ and GH secretion, except for the $10 \mu \mathrm{g}$ dose
\end{abstract}

of NDP-MSH, which exhibited both a stimulatory and an inhibitory effect on $\mathrm{GH}$ secretion in fasted animals. Treatment with agouti-related peptide, a natural brain hormone that blocks the MC3/4R, failed to stimulate feed intake. These results do not support the idea that endogenous melanocortin pays a critical role in regulating feed intake and pituitary hormone secretion in the pig. SHU9119 blocked the NDP-MSH-induced increase in cAMP in HEK293 cells expressing the porcine MC4-R sequence without the missense mutation. The $\mathrm{EC}_{50}$ and $\mathrm{IC}_{50}$ values were similar to the human MC4-R, confirming that SHU9119 is a pig MC4-R antagonist. However, pigs were heterozygous for an MC4-R gene missense mutation. It is possible that the MC4-R mutation alters function and this may explain the failure to demonstrate MC3/4-R involvement in modulating feeding behavior and $\mathrm{LH}$ and $\mathrm{GH}$ secretion in the pig.

Journal of Endocrinology (2004) 181, 39-52

\section{Introduction}

Our knowledge of factors regulating voluntary feed intake in humans and domestic animals is very limited. Much of what is known is based on studies in rodents. Agouti-related peptide (AGRP), produced in the arcuate nucleus of the hypothalamus, is an endogenous antagonist of alpha-melanocyte-stimulating hormone (MSH) at melanocortin-3 and -4 receptor (MC3/4-R) (Ollmann et al. 1997). Secretion of AGRP in the hypothalamus blocks the anorexic effects of alpha-MSH. AGRP, like neuropeptide-Y (NPY), is overexpressed in $d b / d b$ and ob/ob mice (Shutter et al. 1997) and caused hyperphagia and obesity when overexpressed in transgenic mice (Graham et al. 1997). Moreover, administration of an MC4-R antagonist, SHU9119, blocked leptin's inhibition of food intake (Seeley et al. 1997). A recent report by Kask et al. (1998) demonstrated that i.c.v. administration of
HS014 (0.33-10 nmol), a selective antagonist for the MC4-R, increased food intake for up to $4 \mathrm{~h}$ posttreatment in rats. In addition, chronic i.c.v. administration of HS028, an MC4-R antagonist which exhibits higher affinity for the MC4-R receptor than HS014, increased food intake and body weight (BW) for a period of 7 days (Skuladottir et al. 1999). In contrast, stimulation of the MC4-R by central administration of the MC4-R receptor agonist, MTII, reduced food intake and BW at 24 and $48 \mathrm{~h}$ after treatment (Thiele et al. 1998).

Both the MC4-R and MC3-R are predominantly expressed in higher brain centers, but are also expressed in areas within the hypothalamus involved in regulating gonadotropin-releasing hormone $(\mathrm{GnRH})$ (Kraeling \& Barb 1990) and growth hormone (GH)-releasing hormone (Leshin et al. 1994) release and subsequent luteinizing hormone (LH) and $\mathrm{GH}$ secretion. Thus, anatomically the MC3/4-R is well positioned to interact with 
GnRH-producing neurons to modulate reproductive activity. In support of this idea, Watanobe et al. (1999) reported that blockade of MC4-R suppressed the steroidinduced $\mathrm{LH}$ and prolactin (PRL) surges in normal-fed ovariectomized (OVX) rats.

The objective of the present study was two-fold: first, to examine if the MC3/4-R in the brain modulates feed intake and energy homeostasis in pigs, and secondly, to determine if the MC3/4- $\mathrm{R}$ receptor modulates $\mathrm{LH}$ and $\mathrm{GH}$ secretion. These studies were conducted utilizing the pig, a species devoid of brown adipose tissue.

\section{Materials and Methods}

\section{Experiment (EXP) I. Central administration of MC3/4-R antagonist (SHU9119)}

EXP Ia Sixteen OVX crossbred prepuberal gilts, $81 \pm 2 \mathrm{~kg} \mathrm{BW}$ and 130-140 days of age were surgically implanted with i.c.v. cannulas using the stereotaxic procedure of Estienne et al. (1990) and Barb et al. (1993) with the following modification. To facilitate i.c.v. injections, a Silastic tube attached to the stainless steel injection cannula was extended s.c. to the dorsal neck region and exteriorized. Patency was maintained by flushing with sterile physiological saline (Johnson et al. 1994). All procedures were approved by the Richard B Russell Agriculture Research Center Committee on Animal Care and Use. Animals were individually penned in an environmentally controlled building and exposed to a constant temperature of $22{ }^{\circ} \mathrm{C}$ and an artificial $12 \mathrm{~h}$ light: $12 \mathrm{~h}$ darkness photoperiod. Pigs were fed ad libitum a corn-soybean meal ration (14\% crude protein) supplemented with vitamins and minerals, according to NRC guidelines (NRC 1998). Animals were meal fed twice daily and baseline food intake was quantified prior to the onset of the study. One week after the last i.c.v. surgery, all pigs were fitted with an indwelling jugular vein cannula (Barb et al. 1982). Blood samples were collected every $15 \mathrm{~min}$ for $4 \mathrm{~h}$ before and $4 \mathrm{~h}$ after i.c.v. injections of $150 \mu \mathrm{l} 0.9 \%$ saline $(n=4)$ or $0.01 \mathrm{nmol}(n=4), 0.1 \mathrm{nmol}(n=4)$ or $1 \mathrm{nmol}(n=4)$ MC3/4-R antagonist (SHU9119; Bachem, Torrance, CA, USA) in $150 \mu \mathrm{l}$ saline. Serum was harvested and stored at $-20{ }^{\circ} \mathrm{C}$ until assayed for $\mathrm{LH}$ and GH by RIA. Hourly samples were assayed for glucose and free fatty acids (FFA).

EXP Ib One week later the study was repeated with pigs reassigned to treatment. The experiment followed the same protocol described above with the following modifications: i.c.v. injections of $150 \mu \mathrm{l}$ saline $(n=4)$ or $3 \mathrm{nmol}$ $(n=4)$ or $6 \mathrm{nmol}(n=4) \mathrm{MC} 3 / 4-\mathrm{R}$ antagonist, SHU9119, in $150 \mu \mathrm{l}$ saline. Blood samples were not collected.

EXP Ic Six days later pigs were reassigned to i.c.v. treatment and received $3 \mathrm{nmol}(n=3) \mathrm{MC} 3 / 4-\mathrm{R}$ agonist,
$\left[\mathrm{Nle}^{4}, \mathrm{D}-\mathrm{Phe}^{7}\right]-\alpha-\mathrm{MSH}$ (NDP-MSH; Bachem), $100 \mu \mathrm{g}$ human leptin (R\&D Systems, Minneapolis, MN, USA) $(n=4)$ in $150 \mu \mathrm{l}$ saline or $150 \mu \mathrm{l}$ saline $(n=4)$,

Feed intake i.c.v. treatment was administered immediately following consumption of the morning meal. After i.c.v. treatment (time $=0)$, animals were given continuous access to feed, and feed intake was monitored at 2, 4, 8, 12, 24, 48, 72 and $96 \mathrm{~h}$ in EXP Ia and b and at 12, 24, 48 and $96 \mathrm{~h}$ in EXP Ic.

\section{EXP II. Central administration of MC3/4-R agonist (NDP-MSH)}

EXP IIa Eighteen OVX prepuberal gilts, $65 \pm 1 \mathrm{~kg} \mathrm{BW}$ and 120-130 days of age, were surgically implanted with i.c.v. cannulas, housed and fed as described in EXP I. All pigs were randomly assigned to treatment and fitted with an indwelling jugular vein cannula $24 \mathrm{~h}$ before treatment. Feeders were removed and animals fasted for $12 \mathrm{~h}$ prior to i.c.v. treatment. Blood samples were collected every $15 \mathrm{~min}$ for $2 \mathrm{~h}$ before and $6 \mathrm{~h}$ after i.c.v. injections of $150 \mu \mathrm{l}$ saline $(n=4)$ or $0.03 \mathrm{nmol}(n=4), 0.3 \mathrm{nmol}(n=4)$ or $3 \mathrm{nmol}(n=4)$ of MC4-R agonist, NDP-MSH, in $150 \mu \mathrm{l}$ saline. Serum was harvested and stored at $-20{ }^{\circ} \mathrm{C}$ until assayed for LH and GH by RIA. Hourly samples were assayed for glucose and FFA.

EXP IIb One week later gilts were randomly assigned to a $2 \times 2$ factorial arrangement of treatments with the main effects of feeding status (fed vs fasted) and treatment (saline vs NDP-MSH) resulting in the following groups; fed+saline $(n=3)$, fed+NDP-MSH $(n=3)$, fast+saline $(n=4)$ and fast+NDP-MSH $(n=4)$. Feed was removed $24 \mathrm{~h}$ prior to i.c.v. treatment. Blood samples were collected only from the fasted animals and treatments were administered as described above except only $10 \mu \mathrm{g}$ NDP-MSH were utilized.

Feed intake After i.c.v. treatment (time $=0)$ feeders were placed in all pens and feed intake monitored at 12, 24, 48, 72 and $96 \mathrm{~h}$ after feed presentation.

\section{EXP III. Central administration of AGRP, an MC4-R antagonist}

EXP IIIa Eighteen OVX crossbred prepuberal gilts, averaging $70 \pm 1 \mathrm{~kg} \mathrm{BW}$ and 120-130 days of age, were surgically implanted with i.c.v. cannulas using the stereotaxic procedure as described above. Animals were individually penned, housed and fed as described in EXP Ia. Blood samples were collected via venepuncture and each animal genotyped for MC4-R polymorphs. Baseline food intake was quantified prior to the onset of the study. On the day of treatment, feeders were removed $1 \mathrm{~h}$ prior to treatment and pigs received i.c.v. injections of $150 \mu \mathrm{l} 0.9 \%$ saline $(n=4)$ or $0 \cdot 1 \mu \mathrm{g}(n=4), 1 \cdot 0 \mu \mathrm{g}(n=4)$ or $10 \mu \mathrm{g}(n=3)$ 


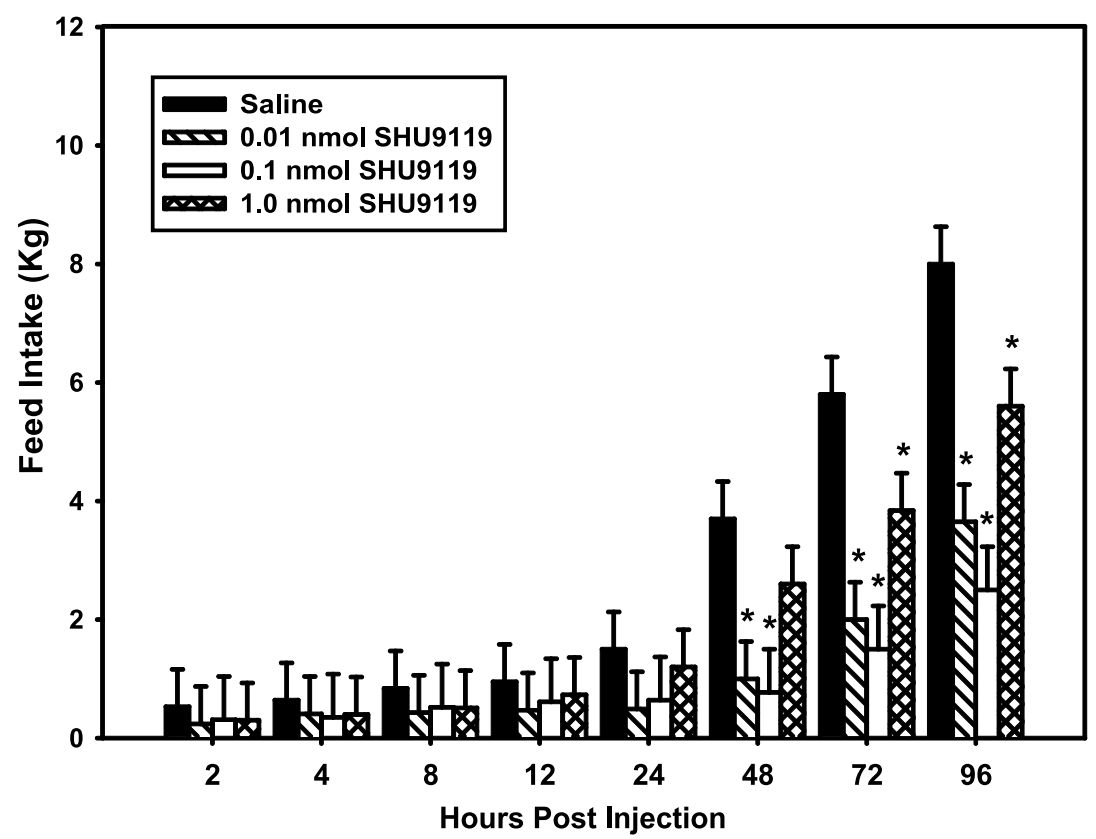

Figure 1 Cumulative feed intake (means \pm S.E.) for pigs receiving i.c.v. injections of saline $(n=4)$ or $0.01 \mathrm{nmol}(n=4), 0.1 \mathrm{nmol}(n=4)$ or $1 \mathrm{nmol}(n=4)$ of MC3/4-R antagonist, SHU9119. A treatment $\times$ time interaction $(P<0.02)$ was detected. Times at which effects of treatment were different from saline-treated animals, ${ }^{*} P<0 \cdot 05$.

of AGRP, an MC4-R antagonist (human AGRP 83-132 amide; Phoenix Pharmaceuticals, Inc., Belmont, CA, USA) in $150 \mu \mathrm{l}$ saline.

EXP IIIb This followed the same protocol described above except for the following modifications: pigs received i.c.v. injections of $150 \mu \mathrm{l}$ saline $(n=4)$ or $18.4 \mu \mathrm{g}(n=3)$, $36.9 \mu \mathrm{g}(n=4)$ or $73.8 \mu \mathrm{g}(n=4)$ of AGRP in $150 \mu \mathrm{l}$ saline.

Feed intake After i.c.v. treatment (time $=0$ ), animals were given continuous access to feed, and feed intake was monitored at 2, 4, 6, 12, 24, 48, 72 and $96 \mathrm{~h}$.

\section{Metabolite and hormone assays}

Serum concentrations of GH (Barb et al. 1991) and LH (Kesner et al. 1987) were quantified by RIA as previously described. Sensitivity of the assays was $0 \cdot 4$ and $0 \cdot 15 \mathrm{ng} / \mathrm{ml}$ for $\mathrm{GH}$ and $\mathrm{LH}$ respectively. Intra- and inter-assay coefficients of variation were $3 \cdot 3$ and $13 \%$ for $\mathrm{GH}$ and $4 \cdot 6$ and $10 \%$ for LH respectively. Samples were assayed for glucose using a glucose oxidase kit (Sigma Chemical Co., St Louis, MO, USA) and FFA using a colorimetric assay kit (Wako Chemical USA, Inc., Richmond, VA, USA).

\section{Mutation detection}

Whole blood lymphocytes were isolated by standard methods (Kendall et al. 1991). The pelleted lymphocytes were suspended in RNAlater (Ambion, Inc., Austin, TX,
USA), held at room temperature overnight and then stored at $-70{ }^{\circ} \mathrm{C}$. The samples were thawed, the RNAlater carefully decanted and the tissues were suspended in cell lysis buffer (Roche Magna Pure DNA isolation kit I; Roche Diagnostics, Mannheim, Germany; $1 \mathrm{ml} / \mathrm{g}$ tissue). Tissues were then homogenized with a Wheaton loose-fitting Dounce homogenizer. Samples were then processed using a Magna Pure LC Robotic Instrument to complete DNA isolation (Roche Diagnostics).

To determine if the animals used in this study carried a mutation in the MC4-R gene, we used primers as described by Kim et al. (2000) to amplify the porcine MC4-R gene from the genomic DNA. Briefly, $0.5 \mathrm{mM}$ forward (tggcaatagccaagaacaag) and reverse (caggggatag caacagatga) primers were mixed with Invitrogen PCR Supermix (Invitrogen, Carlsbad, CA, USA) and $5 \mu \mathrm{l}$ genomic DNA as a template. A Perkin Elmer Applied Biosystems Gene Amp PCR system 9700 thermocycler (Perkin Elmer, Inc., Stamford, CT, USA) was utilized with the following amplification conditions: one cycle $94{ }^{\circ} \mathrm{C}$ for $5 \mathrm{~min}, 30$ cycles at $94^{\circ} \mathrm{C}$ for $1 \mathrm{~min}, 58^{\circ} \mathrm{C}$ for $1 \mathrm{~min}$ and $72^{\circ} \mathrm{C}$ for $1.5 \mathrm{~min}$, followed by one cycle at $72{ }^{\circ} \mathrm{C}$ for $15 \mathrm{~min}$.

The 750 bp product was gel purified (Qiagen Qiaquick Gel Extraction Kit; Qiagen, Inc., Valencia, CA, USA) and used as a template for a second PCR reaction. The second PCR reaction was set up to amplify a smaller portion of the polymorph region so that a Taq1 restriction digest 


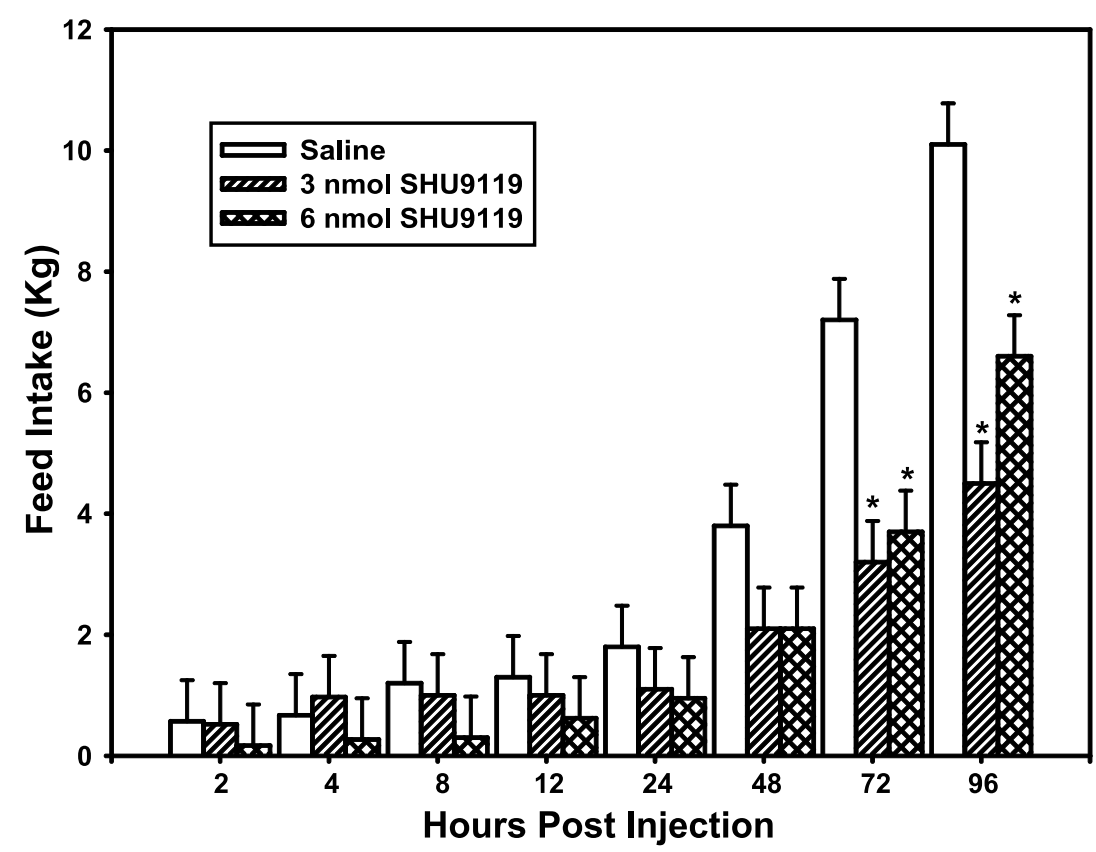

Figure 2 Cumulative feed intake (means \pm S.E.) for pigs receiving i.c.v. injections of saline $(n=4)$ or $3 \mathrm{nmol}(n=4)$ or $6 \mathrm{nmol}(n=4)$ of MC3/4-R antagonist, SHU9119. A treatment $\times$ time interaction $(P<0.01)$ was detected. Times at which effects of treatment were different from saline-treated animals, ${ }^{*} P<0 \cdot 001$.

could identify the single nucleotide polymorphism (TCGA) as described by Kim et al. (2000). The reaction tube contained $2 \mu \mathrm{l}$ template DNA, and PCR Supermix cocktail containing $0.5 \mathrm{mM}$ primers (forward=taccetgac catcttgattg, reverse $=$ atagcaacagatgatctcttt $)$. This PCR reaction was performed under the following amplification conditions: one cycle $94{ }^{\circ} \mathrm{C}$ for $5 \mathrm{~min}, 30$ cycles at $94{ }^{\circ} \mathrm{C}$ for $1 \mathrm{~min}, 56^{\circ} \mathrm{C}$ for $1 \mathrm{~min}$ and $72{ }^{\circ} \mathrm{C}$ for $1.5 \mathrm{~min}$, followed by one cycle $72{ }^{\circ} \mathrm{C}$ for $15 \mathrm{~min}$.

The PCR product was purified (Qiagen Qiaquick PCR Purification Kit; Qiagen), and suspended in $50 \mu \mathrm{l}$ TrisEDTA buffer. A restriction digest in the presence and absence of Taq1 restriction endonuclease (New England Biolabs, Inc., Beverly, MA, USA) was conducted for $2 \mathrm{~h}$. Subsequently, sample buffer was added to the restriction digest and the reaction was electrophoresed on a $2 \%$ agarose/ethidium bromide gel. The gel was illuminated and imaged using a Hitachi Genetic Systems CCDBIO16SC imaging station (MiraiBio, Inc., Alameda, CA, USA). PCR products were sequenced to confirm the inclusion of the single nucleotide polymorphism as described by Kim et al. (2000).

\section{SHU9119, MC4-R antagonist}

The porcine MC4-R open reading frame (Accession No. AB021664) was amplified by RT-PCR using porcine hypothalamic RNA, and cloned into the PCDNA3·1/V5-
HisTOPO vector. This construct was then amplified in $E$. coli and purified using a Qiagen Maxi Prep Kit. The construct was transformed into HEK293A cells using Fugene-6 liposome-mediated transformation reagent (Roche Molecular Biochemicals, Indianapolis, IN, USA). The protocol required a ratio of $5 \mu$ l Fugene- 6 per $1 \mu \mathrm{g}$ construct DNA. After 2 days of incubation in standard growth medium (DMEM; 10\% fetal bovine serum, 0.01\% penicillin/streptomycin (Gibco BRL, Rockville, MD, USA)), the medium was changed to growth medium containing $500 \mu \mathrm{g} / \mathrm{ml}$ geneticin. Stable clones were selected from foci that developed following several weeks of selection. Stable cell lines were chosen based on NDPMSH-stimulated intracellular cAMP accumulation. Individual cell clones yielding a 5- to 10-fold stimulation of intracellular CAMP were further characterized by performing a full dose titration of NDP-MSH SHU9119 (Bachem Biosciences, King of Prussia, PA, USA). Briefly, cells were plated into a 96 -well plate at 15000 cells $/ \mathrm{ml}$ and allowed to grow to confluence (approximately 2 days). Cells were incubated for $30 \mathrm{~min}$ with a full concentration range of NDP-MSH $(2 \mu \mathrm{M}-0.0004 \mathrm{nM})$ in triplicate in the presence of 4 nM SHU9119. All drug solutions were made in a phosphate saline buffer containing $0 \cdot 2 \mathrm{mM}$ isobutylmethylxanthine (Sigma). Incubation was terminated by aspiration followed by addition of $200 \mu \mathrm{l}$ cell lysis buffer. Intracellular cAMP was quantified using the BIOTRAK whole cell cyclic AMP EIA (Amersham, Piscataway, NJ, USA). 


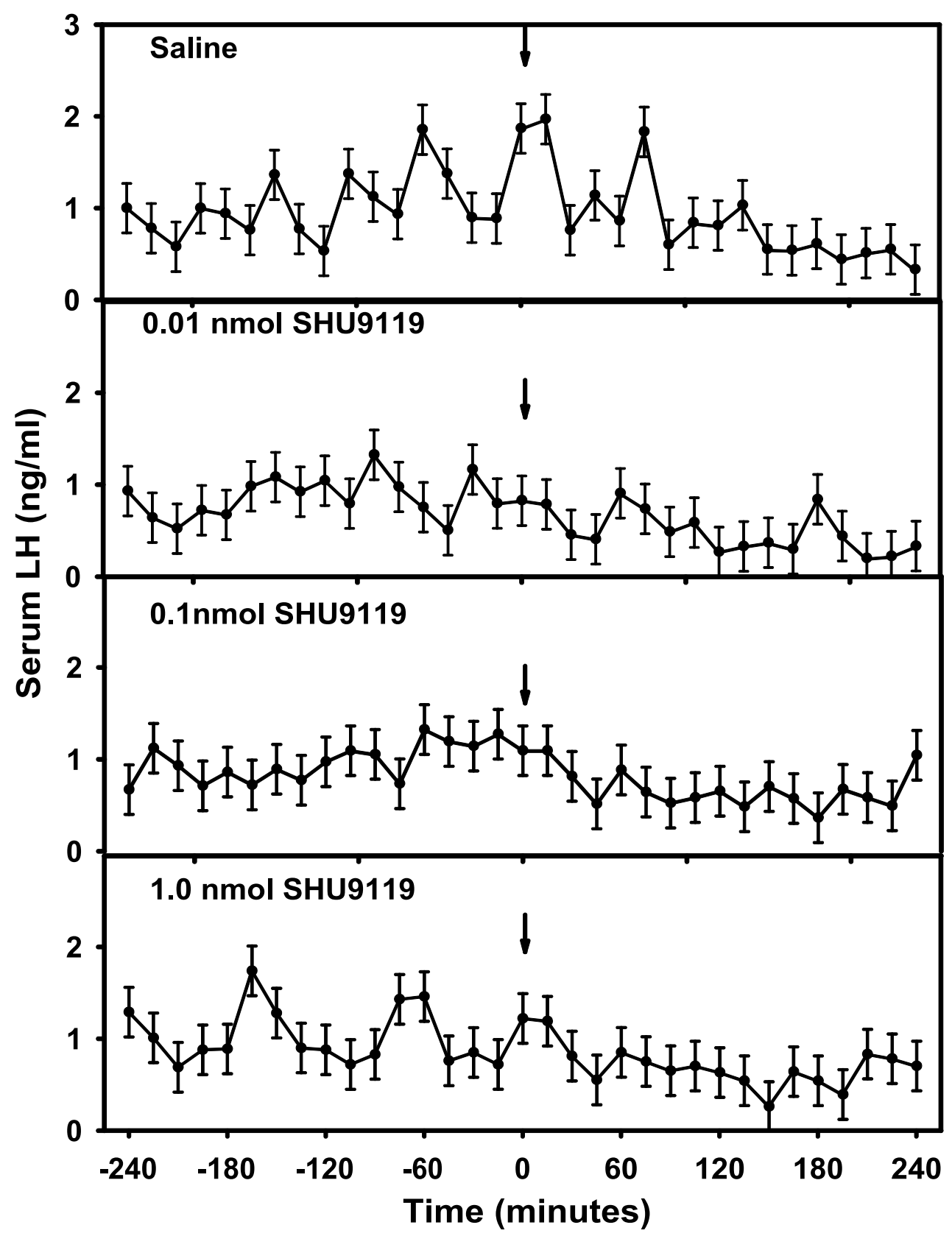

Figure 3 Serum LH concentrations (means \pm S.E.) for pigs receiving i.c.v. injections (time 0 ) of saline $(n=4)$ or $0.01 \mathrm{nmol}(n=4), 0 \cdot 1 \mathrm{nmol}(n=4)$ or $1 \mathrm{nmol}(n=4)$ of MC3/4-R antagonist, SHU9119.

Non-linear regression curve fit was performed using GraphPad Prism (GraphPad Software, San Diego, CA, USA).

\section{Statistical analysis}

To determine the effect of treatment on feed intake and serum LH, GH, glucose and FFA concentrations across time in EXPs I, II and III, data were subjected to the general linear model split plot-in-time ANOVA procedure of the Statistical Analysis System (SAS 1999). The statistical model included dose, pig and time. Effects of dose were tested using animal within dose as the error term. Time was tested using dose $\times$ time as the error term and dose $\times$ time was tested by the residual. Differences between treatment means within a time were determined by least-squares contrasts (SAS 1999). 


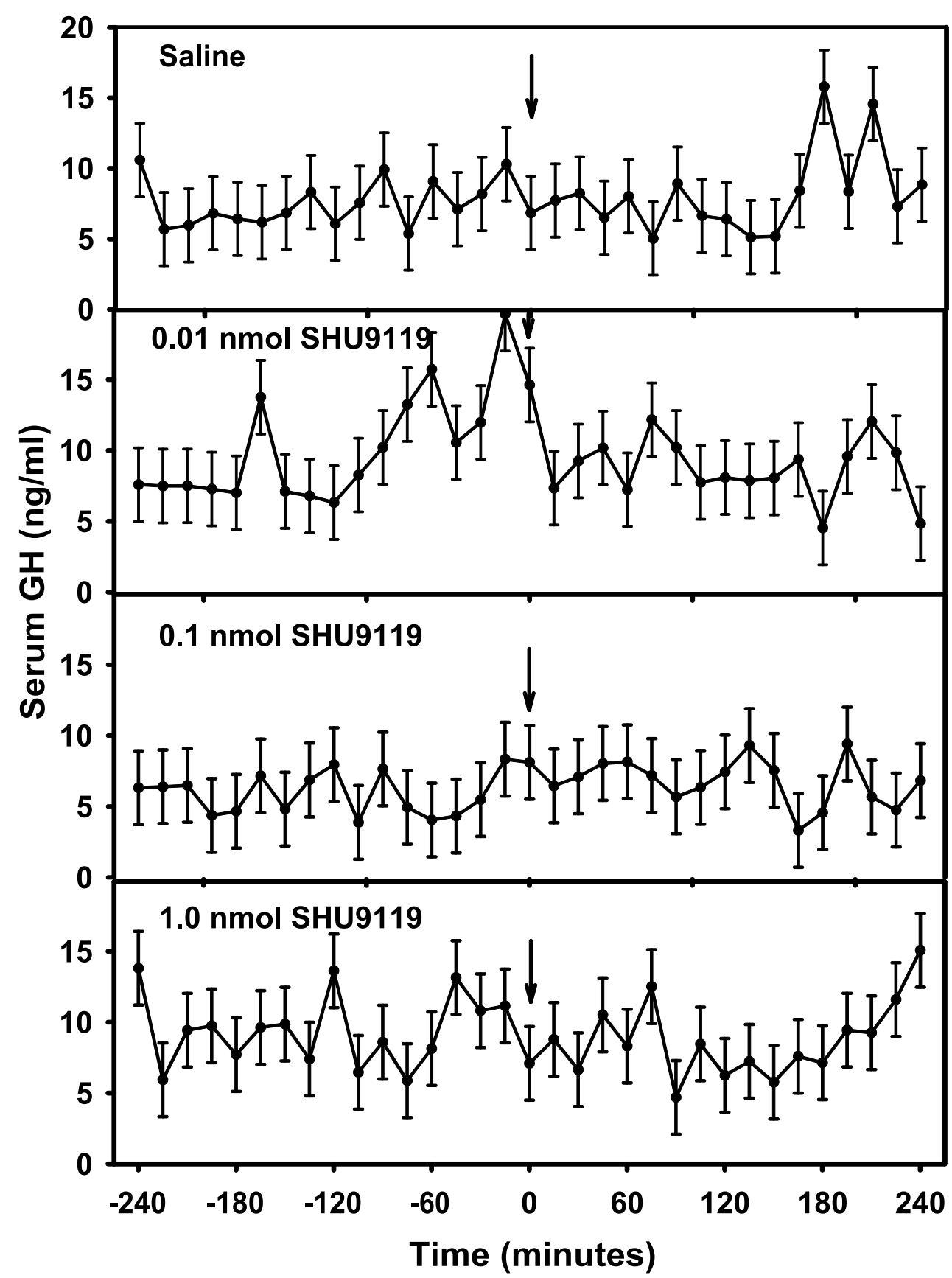

Figure 4 Serum $\mathrm{GH}$ concentrations (means \pm S.E.) for pigs receiving i.c.v. injections (time 0 ) of saline $(n=4)$ or $0 \cdot 01 \mathrm{nmol}(n=4), 0 \cdot 1 \mathrm{nmol}(n=4)$ or $1 \mathrm{nmol}(n=4)$ of MC3/4-R antagonist, SHU9119.

\section{Results}

\section{EXP I}

All doses of SHU9119 failed to increase feed intake compared with saline controls in EXP Ia (Fig. 1) and EXP $\mathrm{Ib}$ (Fig. 2). However, by $48 \mathrm{~h}$ all doses suppressed $(P<0 \cdot 05)$ feed intake compared with saline controls, except for the $1 \mathrm{nmol}$ dose in EXP Ia at $48 \mathrm{~h}$. Serum glucose and FFA were similar among the groups and averaged $134 \pm 43 \mathrm{mg} / \mathrm{dl}$ and $248 \pm 51 \mathrm{mEq} / 1 \mathrm{respec}-$ tively. Treatment with SHU9119 in EXP Ia failed to affect serum LH and GH concentrations (Figs 3 and 4). These results were unexpected and may in part be related to the use of a modified i.c.v. injection system. Thus, EXP Ic was 


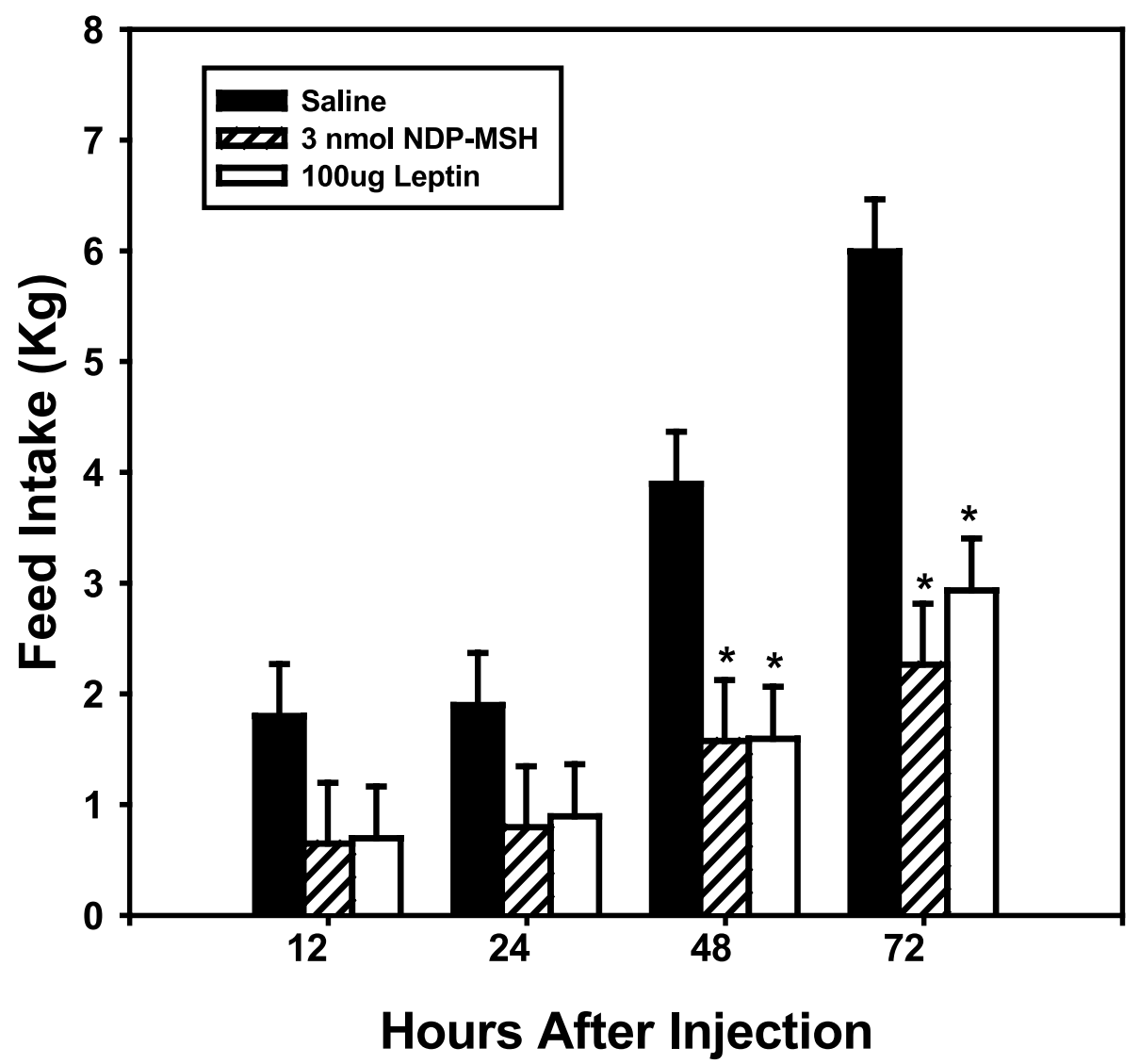

Figure 5 Cumulative feed intake (means \pm S.E.) for pigs receiving i.c.v. injections of saline $(n=4)$, $100 \mu \mathrm{g}$ leptin $(n=4)$ or $3 \mathrm{nmol}(n=3)$ of MC3/4-R agonist, NDP-MSH. Times at which effects of treatment were different from saline-treated animals, ${ }^{*} P<0 \cdot 05$.

conducted to determine if the modified i.c.v. injection system was compromised. We have previously reported that leptin inhibits feed intake in the pig (Barb et al. 1998). Thus, i.c.v. administration of leptin should suppress feed intake. Leptin and NDP-MSH suppressed $(P<0 \cdot 05)$ feed intake by $48 \mathrm{~h}$ (Fig. 5). These results indicate that the i.c.v. injection system was not compromised. The failure of SHU9119 to increase feed intake may in part be related to the dose of SHU9119 employed, therefore EXP Ib was conducted to examine higher doses of SHU9119.

\section{EXP II}

EXP IIa By $12 \mathrm{~h}$ the $0 \cdot 3$ and $3 \mathrm{nmol}$ doses of NDP-MSH reduced $(P<0 \cdot 05)$ feed intake compared with saline controls (Fig. 6). By $24 \mathrm{~h}$, all doses of NDP-MSH suppressed $(P<0 \cdot 05)$ feed intake compared with control animals. However, by $96 \mathrm{~h}$ only the $0 \cdot 3$ and $3 \mathrm{nmol}$ doses continued to suppress feed intake.

EXP IIb There was a nutritional status $\times$ time interaction $(P<0 \cdot 001)$. In fed animals NDP-MSH suppressed
$(P<0.06)$ feed intake at all times. In contrast, NDP-MSH suppressed feed intake at $12 \mathrm{~h}(P<0 \cdot 08), 48 \mathrm{~h}$ and $72 \mathrm{~h}$ $(P<0 \cdot 02)$ after treatment in fasted animals (Fig. 7). Serum LH and GH concentrations were unaffected by NDPMSH treatment in EXP IIa (data not shown). In EXP IIb, a treatment $\times$ time interaction was detected for $\mathrm{GH}$ $(P<0 \cdot 001)$. Serum GH concentrations increased $(P<0.05)$ by $45 \mathrm{~min}$ after i.c.v. injection of $10 \mu \mathrm{g}$ NDPMSH and decreased $(P<0.05)$ during $6 \mathrm{~h}$ after treatment (Fig. 8). However, serum LH concentrations were unaffected by treatment. Serum glucose and FFA were similar among the groups in EXP IIa and $\mathrm{b}$ and averaged $123 \pm 16 \mathrm{mg} / \mathrm{dl}$ and $307 \pm 75 \mathrm{mEq} / \mathrm{l}$ and $121 \pm 14 \mathrm{mg} / \mathrm{d}$ and $411 \pm 68 \mathrm{mEq} / \mathrm{l}$, respectively.

\section{EXP IIIa and $b$}

The failure of the MC3/4-R antagonist SHU9119 (EXP $\mathrm{Ia}$ and $\mathrm{Ib}$ ) to stimulate feed intake suggests involvement of other brain peptide(s) such as AGRP, which antagonize the action of SHU9119 at the MC3/4-R. In EXP IIIa, a treatment $\times$ time interaction was detected $(P<0 \cdot 01)$. Fed 


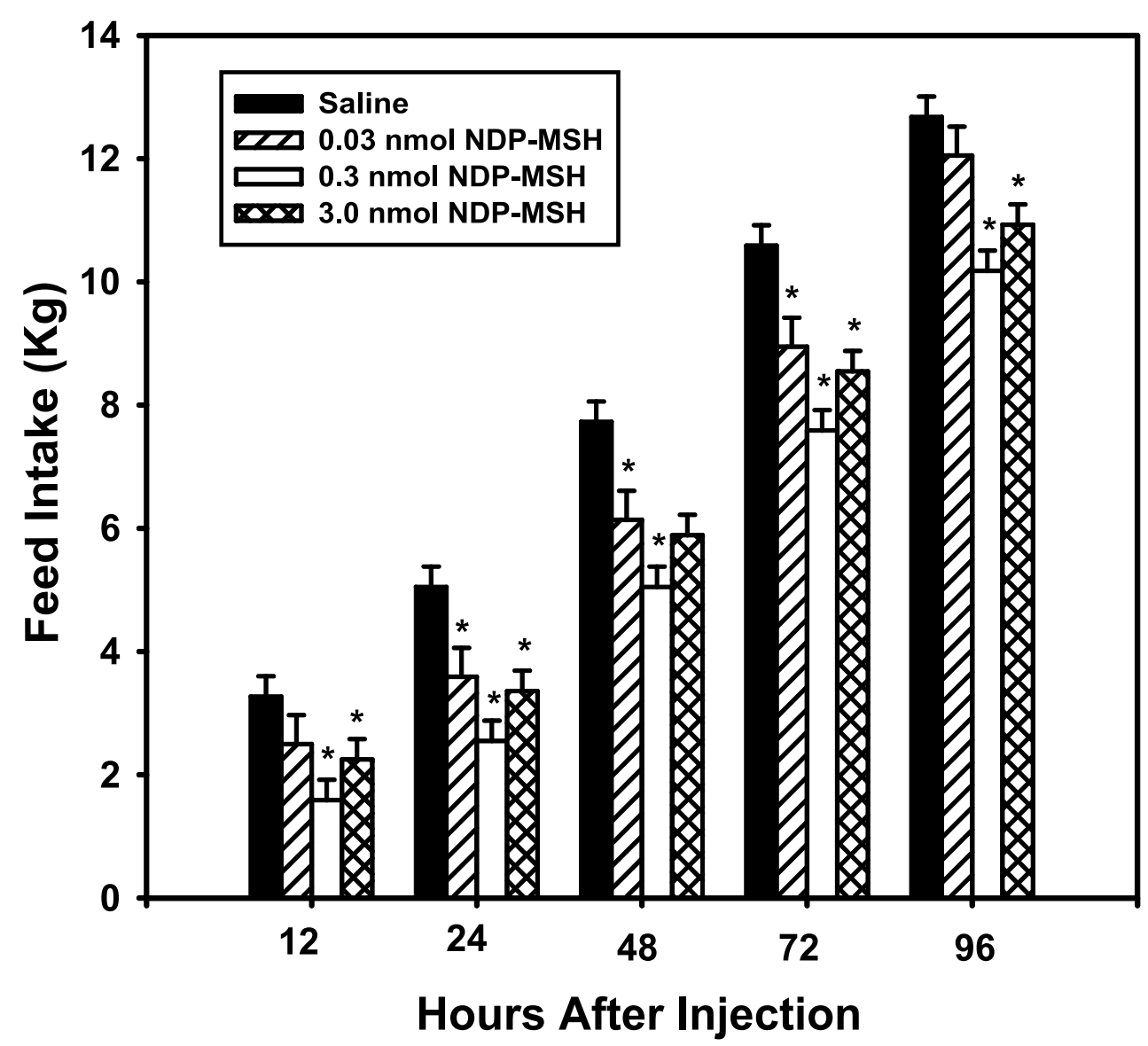

Figure 6 Cumulative feed intake (means \pm S.E.) for pigs receiving i.c.v. injections of saline $(n=4)$ or $0.03 \mathrm{nmol}(n=4), 0.3 \mathrm{nmol}(n=4)$ or $3 \mathrm{nmol}(n=4)$ of MC4-R agonist, NDP-MSH. Times at which effects of treatment were different from saline-treated animals, ${ }^{*} P<0 \cdot 05$.

intake was reduced $(P<0 \cdot 05)$ by the $1 \mu \mathrm{g}$ dose by $48 \mathrm{~h}$ and by the $10 \mu \mathrm{g}$ dose by $72 \mathrm{~h}$ after treatment compared with saline-treated animals (Fig. 9). In EXP IIIb, AGRP increased $(P<0.05)$ feed intake after the $18.4 \mu \mathrm{g}$ dose and at $24 \mathrm{~h}$ after the $73.8 \mu \mathrm{g}$ dose compared with saline controls (Fig. 10). In contrast, the $36.9 \mu \mathrm{g}$ dose suppressed $(P<0 \cdot 05)$ feed intake at 48, 72 and $96 \mathrm{~h}$ compared with saline controls (Fig. 10). Sequenced PCR products from genomic DNA demonstrated that pigs were heterozygous for an Asp-298-Asn single nucleotide polymorphism in the MC4-R gene (Fig. 11).

\section{SHU9119, MC4-R antagonist}

The MC4-R-mediated cAMP response to NDP-MSH was effectively blocked by SHU9119 in HEK293A cells expressing the porcine MC4-R that did not have the missense mutation (Fig. 12).

\section{Discussion}

The control of feeding involves a complex network of central neuronal pathways and peripheral physiological feedback mechanisms (Matteri 2001). Within the central nervous system, regulation of appetite and BW involve several neuropeptides, which include NPY, corticotropinreleasing hormone, cocaine- and amphetamine-regulated transcript, galanin, orexin and melanin concentrating hormone and peripheral signals such as leptin and insulin, which act to mediate hypothalamic activity (Lawrence et al. 1999, Matteri 2001). Feed intake may be regulated primarily by NPY, proopiomelanocortin and AGRP, with leptin being the primary peripheral signal regulating the activity of these peptides. Recent evidence suggests that the melanocortin system, specifically signaling emanating from MC4-R, is a major pathway in regulating feeding behavior (Murphy et al. 1998, Cone 1999). In the present study, administration of an MC3/4-R agonist, NDP- 


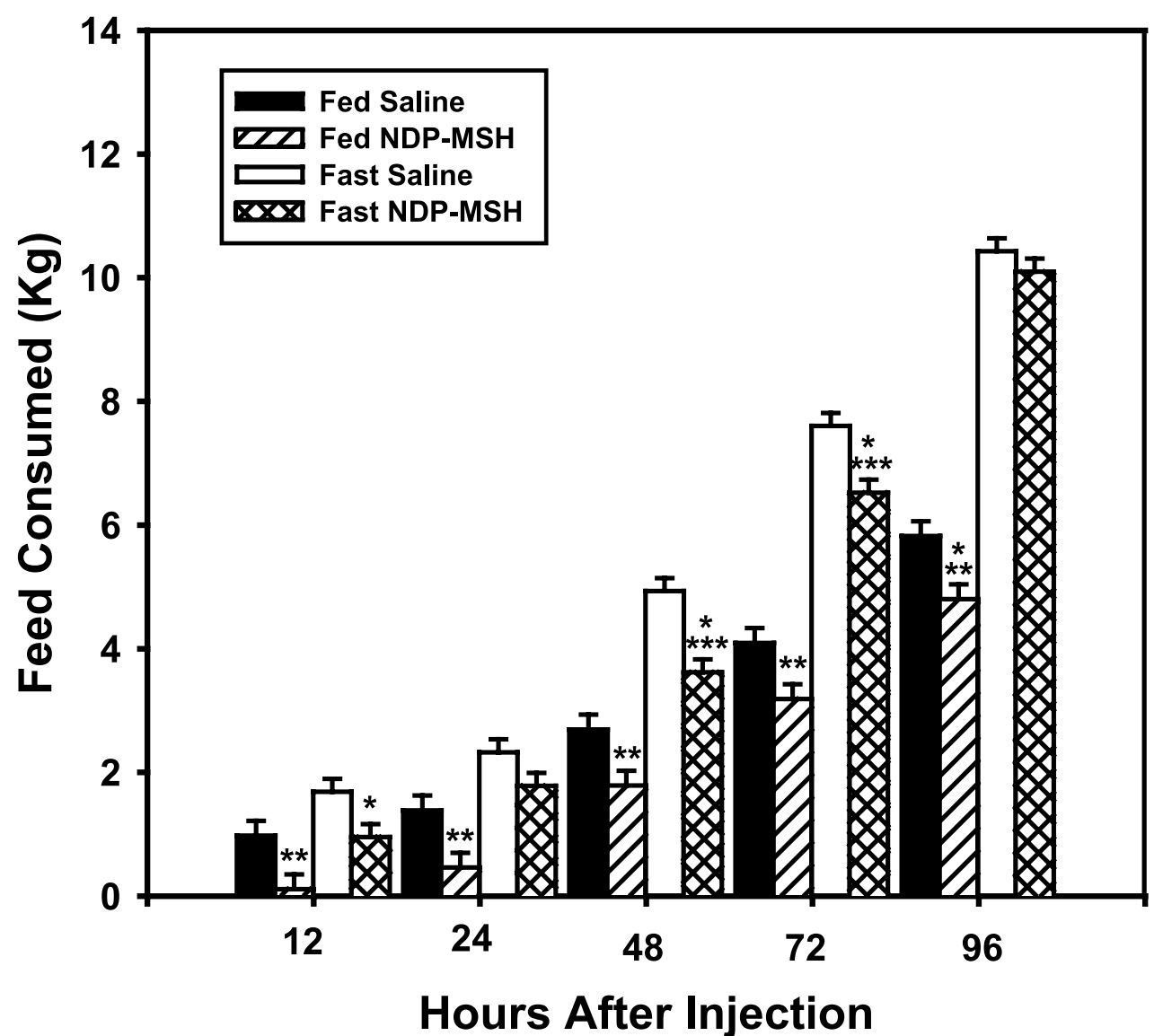

Figure 7 Cumulative feed intake (means \pm S.E.) for pigs fed freely or fasted (fed vs fasted) and pigs receiving i.c.v. injections of saline or $10 \mu \mathrm{g}$ MC4-R agonist, NDP-MSH (saline vs NDP-MSH) resulting in the following groups; fed+saline $(n=3)$, fed+NDP-MSH $(n=3)$, fast+saline $(n=4)$ and fast+NDP-MSH $(n=4)$. A nutritional status $\times$ time interaction was detected $(P<0 \cdot 001)$. Times within nutritional status at which effects of treatment were different from saline-treated animals, ${ }^{\star} P<0 \cdot 08,{ }^{* \star} P<0 \cdot 06,{ }^{* * *} P<0 \cdot 05$, $* * * * P<0 \cdot 02$.

MSH, suppressed feed intake compared with controls at $12,24,48$ and $72 \mathrm{~h}$ after treatment in growing pigs. Fed pigs were more responsive to the MC3/4-R agonist then fasted animals. Thus, one might predict that central administration of the MC4-R antagonist would stimulate feed intake. However, treatment with MC4-R antagonist, SHU9119, across a wide dose range, failed to stimulate intake, suggesting involvement of other brain hormone(s) such as AGRP, which antagonize the action of SHU9119 at the MC4-R, blocking its stimulatory effect on feeding behavior.

AGRP mRNA has been identified in the hypothalamus and pituitary in the pig (Dyer et al. 2000), rat (Shutter et al. 1997) and primate (Haskell-Luevano et al. 1999). AGRP acts as an endogenous antagonist of the MC3-R and MC4-R (Ollmann et al. 1997, Rossi et al. 1998). In mice, central administration of AGRP or the MC4-R antagonist SHU9119 robustly increased feeding behavior, indicating that antagonism of the MC4-R is an important orexigenic signal (Giraudo et al. 1998, Wirth \& Giraudo 2000). Thus, AGRP effects on feed intake appear to require a functional MC4-R. In the present study, AGRP exhibited both antagonistic and agonistic effects on feed intake. The failure of i.c.v. administration of AGRP to consistently stimulate feed intake supports the idea that the melanocortin system does not play a critical role in regulating appetite in the pig, or alternatively there are missense variants of the MC4-R associated with feed intake traits. In the human, missense mutations in the MC4-R have been identified (Hinney et al. 1999) and mutations in MC4-R have been implicated as an underlying factor in a significant population of obese human patients (4-5\% of morbid obesity; Farooqi et al. (2000)). Furthermore, a recent report (Kim et al. 2000) demonstrated that a missense variant of the porcine MC4-R gene is associated with fatness, growth and feed intake traits. This report revealed a missense mutation at a highly conserved region that replaces aspartic acid with 


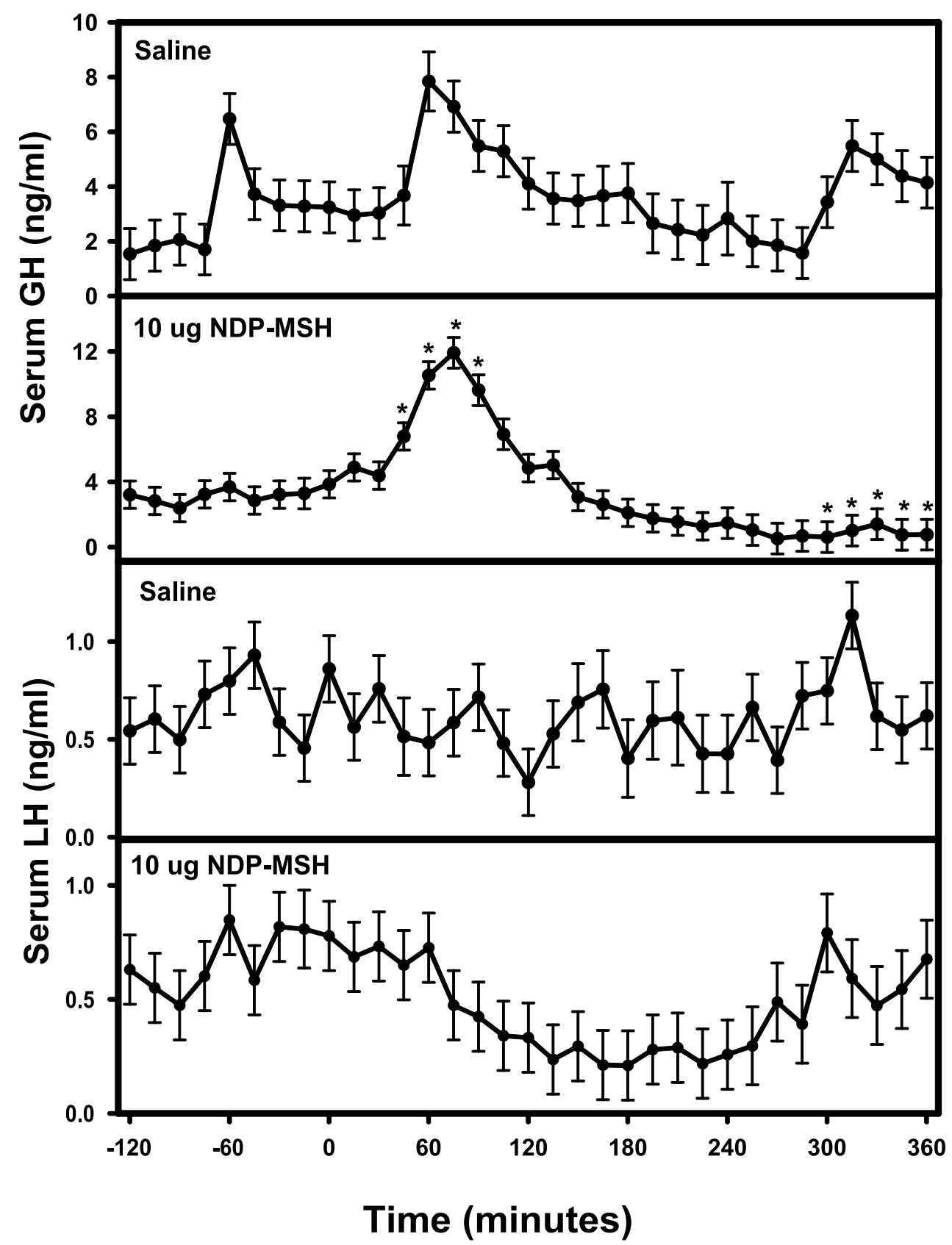

Figure 8 Serum $\mathrm{LH}$ and $\mathrm{GH}$ concentrations (means \pm S.E.) for fasted pigs receiving i.c.v. injections (time 0) of saline $(n=4)$ or $10 \mu \mathrm{g}$ MC4-R agonist, NDP-MSH $(n=4)$. A treatment $\times$ time interaction was detected for $\mathrm{GH}(P<0 \cdot 001)$. Times at which effects of treatment were different from saline-treated animals, ${ }^{\star} P<0.05$.

asparagine at amino acid 298, the position identical to human MC4-R protein (Kim et al. 2000). A structure and function relationship has been observed in natural and experimentally induced MC-R mutations in humans (Valverde et al. 1995, Frandberg et al. 1997) and mice (Robbins et al. 1993). In the present study, all pigs were heterozygous for the MC4-R genotype as described by Kim et al. (2000). It is possible that this MC4-R mutation alters MC4-R function and in part may explain the agonistic effects of SHU9119 and AGRP on feed intake. Furthermore, it should be noted that that the porcine MC4-R sequence used to make the HEK293 cell line did 


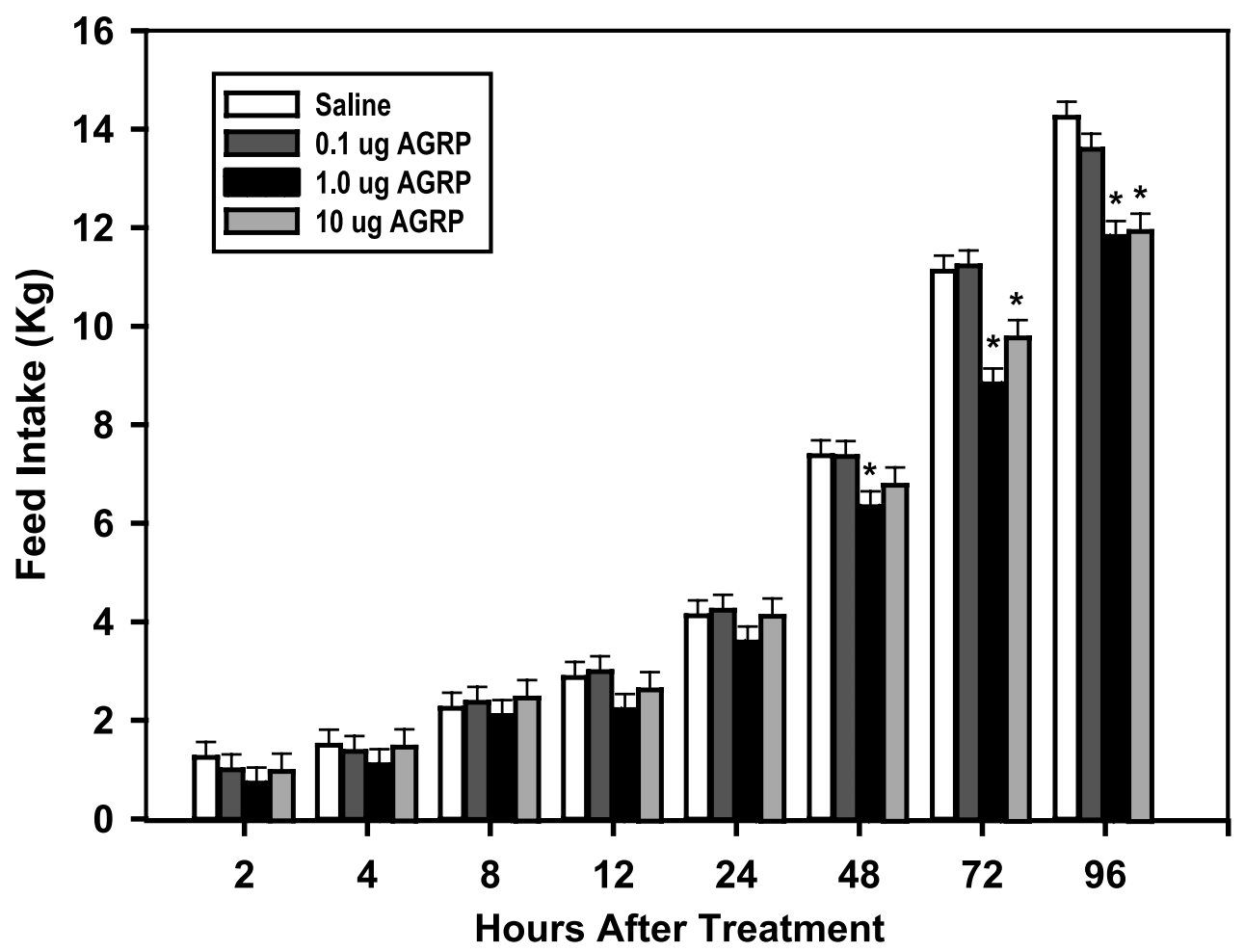

Figure 9 Cumulative feed intake (means \pm S.E.) for pigs receiving i.c.v. injections of saline $(n=4)$ or $0 \cdot 1 \mu \mathrm{g}$ $(n=4), 1 \cdot 0 \mu \mathrm{g}(n=4)$ or $10 \mu \mathrm{g}(n=3)$ of AGRP. A treatment $\times$ time interaction was detected $(P<0 \cdot 01)$. Fed intake was reduced $\left({ }^{\star} P<0 \cdot 05\right)$ by the $1 \mu \mathrm{g}$ dose by $48 \mathrm{~h}$ and the $10 \mu \mathrm{g}$ dose by $72 \mathrm{~h}$ after treatment compared with saline-treated animals.

not have the missense mutation. Moreover, the $\mathrm{EC}_{50}$ and $\mathrm{IC}_{50}$ values reported herein for the pig are similar to those reported for the human MC4-R (Li et al. 1999, Grieco et al. 2002), confirming that it is possible for the wild type pig MC4-R to respond to SHU9119. Thus, a functional MSH antagonist pathway may be related to MC4-R genotype expressed.

The action of leptin and NDP-MSH on feed intake does not support the idea of a non-functional MC4-R. Centrally, the action of leptin is mediated in part by a reduction in hypothalamic AGRP expression and increased MC4-R activity (Wilson et al. 1999). Alternatively, hypothalamic NPY is a potential target in mediating appetite (Blum 1997). Thus, the action of leptin on feed intake in the present study may be mediated by other appetiteregulatory mechanisms. However, the action of NPD$\mathrm{MSH}$, an MC3/4-R agonist, to inhibit feed intake suggests the presence of a functional MC4-R and MC3-R. This dichotomy may be attributable to the MC4-R variants possessing functionally distinct characteristics in the regulation of feed intake and BW, thus explaining the reduction in feed intake following SHU9119 administration. Further work is needed to fully characterize the functional consequences of this MC4-R mutation and implications on regulation of feeding and metabolism in pigs. Moreover, highly conserved residues in the MC4-R protein structure may be critical for ligand binding and signal transduction (Tatro 1996, Oosterom et al. 2001).

In the present study, acute i.c.v. injections of the MC3/4-R antagonist SHU9119 or the agonist NDP$\mathrm{MSH}$, across a wide dose range, failed to influence $\mathrm{LH}$ or GH secretion, except for the $10 \mu \mathrm{g}$ dose of NDP-MSH, which exhibited both a stimulatory and an inhibitory effect on GH secretion in fasted animals. These findings are in partial agreement with a recent report in which chronic i.c.v. infusion of $10 \mathrm{nmol} /$ day SHU9119 for 7 days increased feed intake with no apparent effect on the reproductive and somatotropic axis in male rats (Raposinho et al. 2000). This paradox may, in part, be related to species, gender, nutritional status or treatment differences. Perhaps during nutrient deprivation the somatotropic axis is more sensitive to activation of the MC4-R. Although the role of the MC3/4-R in modulating $\mathrm{GH}$ secretion was equivocal, the effects on $\mathrm{LH}$ secretion were not apparent. Furthermore, no disruption in reproductive function was observed in mice overexpressing agouti (Wolf et al. 1986, Klebig et al. 1995), AGRP (Graham et al. 1997, Ollmann et al. 1997) or in MC4-R knockout mice (Huszar et al. 1997). These observations are consistent with the idea that the 


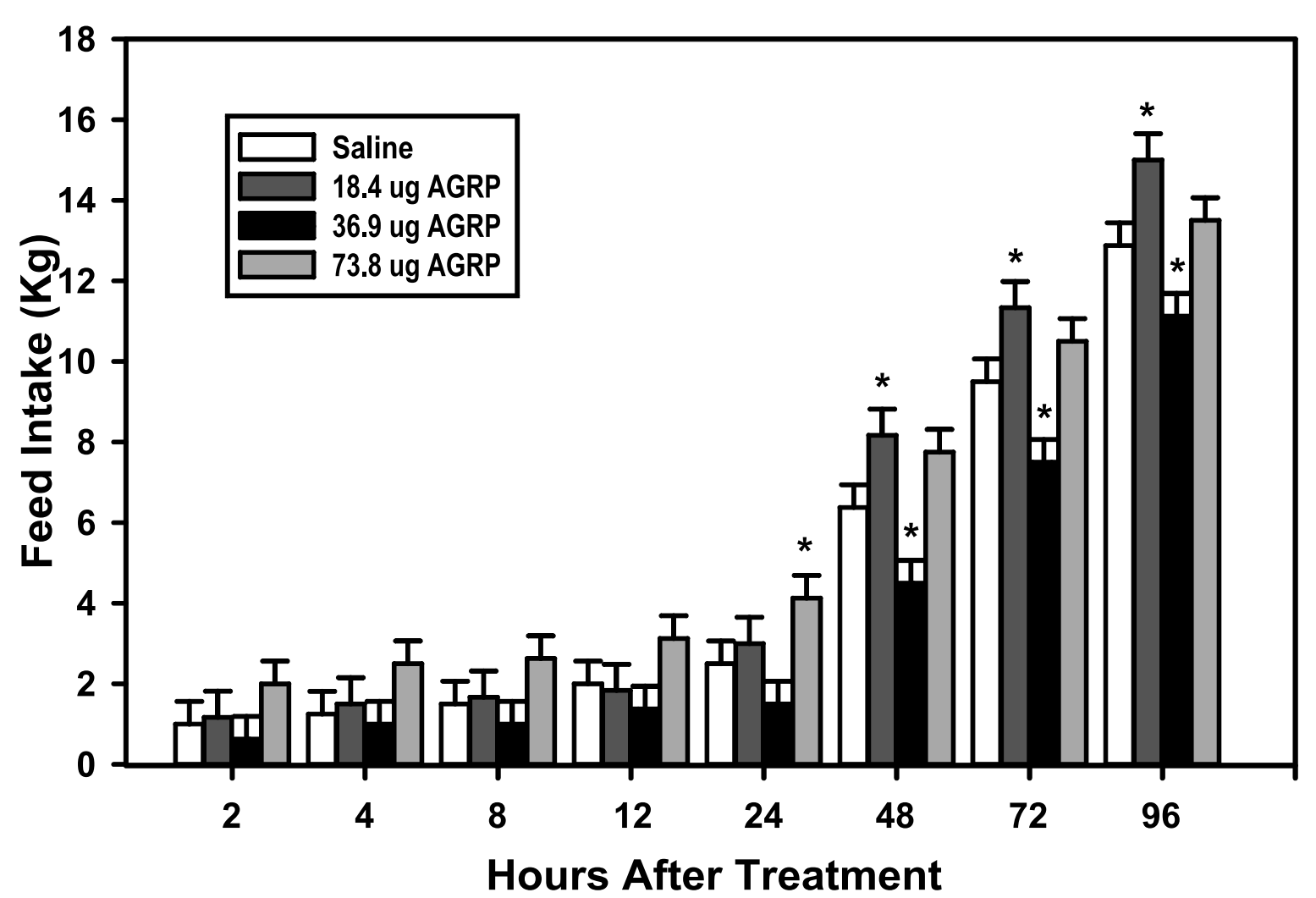

Figure 10 Cumulative feed intake (means \pm S.E.) for pigs receiving i.c.v. injections of saline $(n=4)$ or $18.4 \mu \mathrm{g}(n=3), 36.9 \mu \mathrm{g}$ $(n=4)$ or $73.8 \mu \mathrm{g}(n=4)$ of AGRP. Times at which effects of treatment were different from saline-treated animals, ${ }^{*} P<0 \cdot 05$.

melanocortin system does not regulate the gonadotropic axis. In contrast to this idea, i.c.v. injections of the MC3/4-R antagonists, SHU9119 and HS014, suppressed the magnitude of the LH and PRL surges in normal-fed steroid-primed OVX rats (Wantanobe et al. 1999), while blockade of the MC3/4-R with AGRP blocked the LH

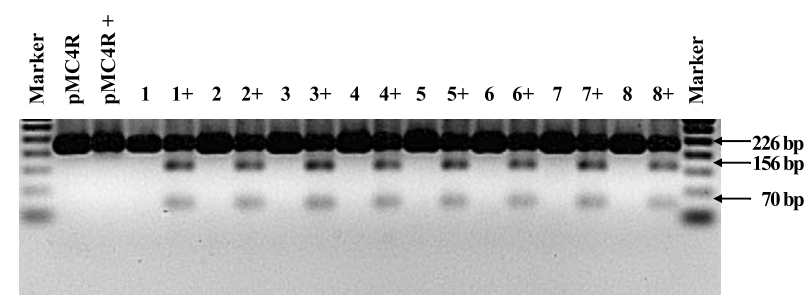

Figure 11 Identification of a mutation in the porcine MC4-R gene. Identification of a G6A substitution in the porcine MC4-R gene by Taq1 digestion of PCR products as described in Materials and Methods. Genomic DNA from representative animals (1-8) were used as a PCR template. The $(+)$ symbol denotes the addition of Taq 1 restriction enzyme into the restriction digest mixture. Invitrogen $50 \mathrm{bp}$ markers were included to determine the approximate size of DNA fragments. A porcine MC4-R (pMC4-R) clone (sequence identical to Genbank AB021664), which does not contain the single nucleotide polymorphism, was included as a control. and PRL surges (Schioth et al. 2001). It is important to note that the estradiol-induced LH and PRL surges in female rats have no corresponding mechanism in male rats. Moreover, the neuroendocrine mechanisms that regulate surge hormone secretion are very different from mechanisms regulating tonic hormone secretion (Kraeling \& Barb 1990). Thus the role of the melanocortins in regulating LH and GH secretion may in part be species-, gender- and steroid-dependent.

In summary, although it was demonstrated that SHU9119 is an MC4-R antagonist in the pig, blockade of the MC3/4-R with SHU9119 and AGRP failed to stimulate appetite, while NPD-MSH, an MC3/4-R agonist, inhibited feed intake, suggesting the presence of a functional MC4-R and MC3-R. This paradox may be attributable to the MC4-R variants possessing functionally distinct characteristics in the regulation of appetite, or alternatively the melanocortin system does not play a primary role in regulating feed intake in the pig. Furthermore, based on the experimental paradigm used in the present study the melanocortin system does not appear to regulate tonic $\mathrm{LH}$ secretion, while the effects on $\mathrm{GH}$ secretion are equivocal. More detailed examination of the physiological role of the melanocortins in modulating LH and $\mathrm{GH}$ secretion is needed. 

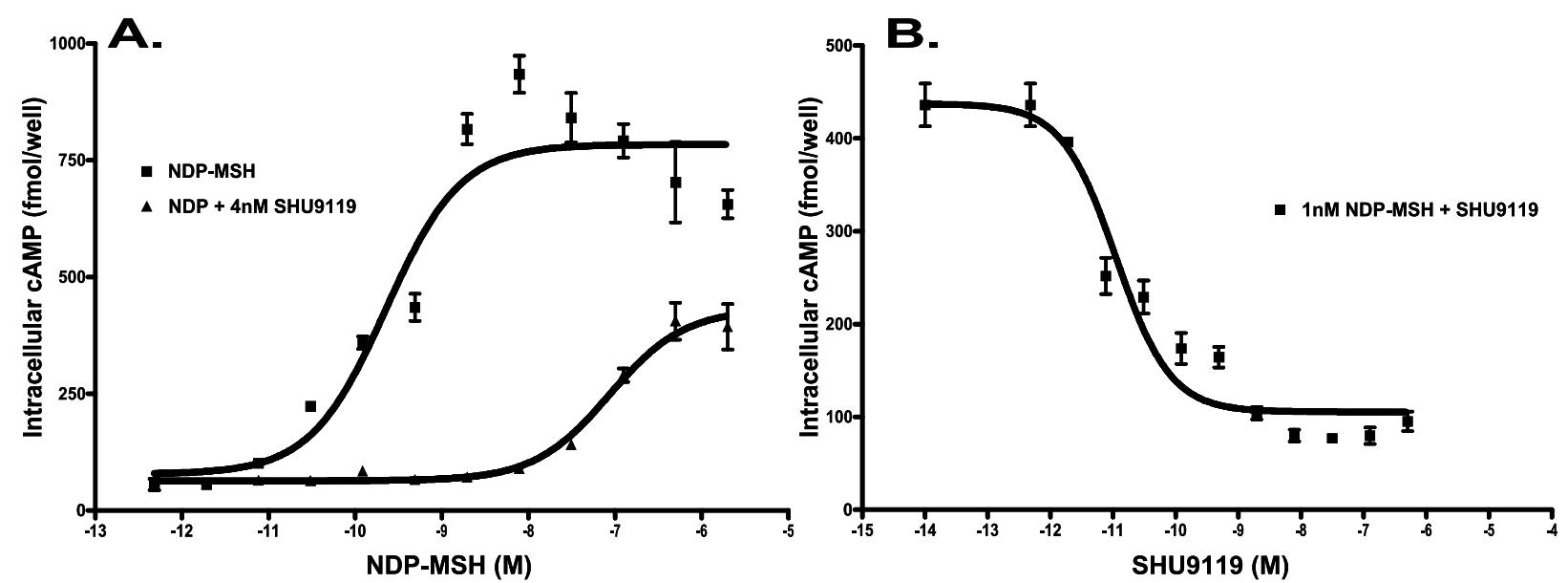

Figure 12 The melanocortin receptor antagonist, SHU9119, is a potent antagonist of NDP-MSH-stimulated porcine MC4R activity. (A) HEK293 cells stably overexpressing wild type porcine MC4-R were treated with increasing concentrations of NDP-MSH in the absence or presence of $4 \mathrm{nM}$ SHU9119 as described in Materials and Methods. NDP-MSH stimulated porcine MC4-R activation as indicated by increased cAMP concentrations in a dose-dependent manner ( $\mathrm{EC}_{50} 268 \pm 103 \mathrm{pM}$ ). SHU9119 (4 nM) inhibited this activation $\left(\mathrm{EC}_{50} 85000 \pm 2950 \mathrm{pM}\right.$ ). (B) HEK293 cells stably overexpressing wild type porcine MC4-R were treated with $1 \mathrm{nM}$ of the melanocortin receptor agonist, NDP-MSH, and various concentrations of SHU9119 as described in Materials and Methods. SHU9119 potently antagonized NDP-MSH-stimulated activity $\left(\mathrm{IC}_{50} 11 \cdot 12 \pm 4 \cdot 42 \mathrm{pM}\right)$.

In conclusion, the role of the MC4-R pathway in regulating feed intake in the pig appears to be MC4-R genotype-dependent.

\section{Acknowledgements}

The authors wish to thank Dr A F Parlow, Harbor-UCLA Medical Center, Torrance, CA for providing the porcine GH antiserum AFP-1021854.

\section{Funding}

This research was supported by a Cooperative Research and Development Agreement between the USDA and Pfizer, Inc. Mention of a trade name, proprietary product, or specific equipment does not constitute a guarantee or warranty by the US Department of Agriculture and does not imply its approval to the exclusion of other products that may be suitable. The authors have no conflicts of interest that would prejudice the impartiality of this manuscript.

\section{References}

Barb CR, Kraeling RR, Rampacek GB, Fonda ES \& Kiser TE 1982 Inhibition of ovulation and LH secretion in the gilt after treatment with ACTH or hydrocortisone. Journal of Reproduction and Fertility 64 85-92.

Barb CR, Estienne MJ, Kraeling RR, Marple DN, Rampacek GB, Rahe CH \& Sartin JL 1991 Endocrine changes in sows exposed to elevated ambient temperature during lactation. Domestic Animal Endocrinology 8 117-127.
Barb CR, Kraeling RR, Estienne MJ \& Rampacek GB 1993 Technique for cannulation of the lateral ventricle of the brain in swine. Kopf Carrier 35 1-5.

Barb CR, Yan X, Azain MJ, Kraeling RR, Rampacek GB \& Ramsay TG 1998 Recombinant porcine leptin reduces feed intake and stimulates growth hormone secretion in swine. Domestic Animal Endocrinology 15 77-86.

Blum WF 1997 Leptin: the voice of the adipose tissue. Hormone Research 48 2-8.

Cone RD 1999 The central melanocortin system and energy homeostasis. Trends in Endocrinology and Metabolism 10 211-216.

Dyer CJ, Touchette KJ, Allee GL, Carroll JA \& Matteri RL 2000 Porcine melanocortin agouti-related peptide: cloning, tissue distribution and quantitation of size-related differences in gene expression. Journal of Animal Science 78 (Suppl 2) 45.

Estienne MJ, Kesner JS, Barb CR, Kraeling RR, Rampacek GB \& Estienne CE 1990 Gonadotropin and prolactin secretion following intraventricular administration of morphine in gilts. Proceedings of the Society for Experimental Biology and Medicine 193 92-97.

Farooqi IS, Yeo GS, Keogh JM, Aminian S, Jebb SA, Butler G, Cheetham T \& O'Rahilly S 2000 Dominant and recessive inheritance of morbid obesity associated with melanocortin 4 receptor deficiency. Journal of Clinical Investigation 106 271-279.

Frandberg P, Xu X \& Chhajlani V 1997 Glutamine $^{235}$ and $\operatorname{arginine}^{272}$ in human melanocortin-5 receptor determines its low affinity to MSH. Biochemical and Biophysical Research Communications 236 489-492.

Giraudo SQ, Billington CJ \& Levine AS 1998 Feeding effects of hypothalamic injection of melanocortin 4 receptor ligands. Brain Research 809 302-306.

Graham M, Shutter JR, Sarmiento U, Sarosi I \& Stark KL 1997 Overexpression of Agrt leads to obesity in transgenic mice. Nature Genetics 17 273-274.

Grieco P, Lavecchia A, Cai M, Trivedi D, Weinberg D, MacNeil T, Van der Ploeg LHT \& Hruby VJ 2002 Structure-activity studies of the melanocortin peptides: discovery of potent and selective affinity antagonists for the hMC3 and hMC4 Receptors. Journal of Medicinal Chemistry 45 5287-5294. 
Haskell-Luevano C, Chen P, Li C, Chang K, Smith MS, Cameron JL \& Cone RD 1999 Characterization of the neuroanatomical distribution of agouti-related protein immunoreactivity in the rhesus monkey and the rat. Endocrinology 140 1408-1415.

Hinney A, Schmidt A, Nottebom K, Heibult O, Becker I, Ziegler A, Gerber G, Sina M, Gorg T, Mayer H et al. 1999 Several mutations in the melanocortin-4 receptor gene including a nonsense and a frameshift mutation associated with dominantly inherited obesity in humans. Journal of Clinical Endocrinology and Metabolism $\mathbf{8 4}$ 1483-1486.

Huszar D, Lynch CA, Fairchild-Huntress V, Dunmore JH, Fang Q, Berkemeier LR, Gu W, Kesterson RA, Boston BA, Cone RD et al. 1997 Targeted disruption of the melanocortin-4 receptor results in obesity in mice. Cell $\mathbf{8 8}$ 131-141.

Johnson RW, von Borell EH, Anderson LL, Kojic LD \& Cunnick JE 1994 Intracerebroventricular injection of corticotropin-releasing hormone in the pig: acute effects on behavior, adrenocorticotropin secretion, and immune suppression. Endocrinology 135 642-648.

Kask A, Rago L, Mutulis F, Pahkla R, Wikberg JES \& Schioth HB 1998 Selective antagonist for the melanocortin 4 receptor (HS014) increases food intake in free-feeding rats. Biochemical and Biophysical Research Communications 245 90-93.

Kendall L, Byerley DJ \& Dean R 1991 Isolation of DNA from blood. Analytical Biochemistry 5 74-76.

Kesner JS, Kraeling RR, Rampacek GB \& Johnson B 1987 Absence of an estradiol-induced surge of luteinizing hormone in pigs receiving unvarying pulsatile gonadotropin-releasing hormone stimulation. Endocrinology 121 1862-1869.

Kim KS, Larsen N, Short T, Plastow G \& Rothschild MF 2000 A missense variant of the porcine melanocortin-4 receptor (MC4R) gene is associated with fatness, growth, and feed intake traits. Mammalian Genome 11 131-135.

Klebig ML, Wilkinson JE, Geisler JG \& Woychik RP 1995 Ectopic expression of the agouti gene in transgenic mice causes obesity, features of type II diabetes, and yellow fur. PNAS 92 4728-4732.

Kraeling RR \& Barb CR 1990 Hypothalamic control of gonadotrophin and prolactin secretion in pigs. Journal of Reproduction and Fertility. Supplement 40 3-17.

Lawrence CB, Turnbull AV \& Rothwell NJ 1999 Hypothalamic control of feeding. Current Opinion in Neurobiology 9 778-783.

Leshin LS, Barb CR, Kiser TE, Rampacek GB \& Kraeling RR 1994 Growth hormone-releasing hormone and somatostatin neurons within the porcine and bovine hypothalamus. Neuroendocrinology 59 251-264.

Li SZ, Lee JH, Lee W, Yoon CJ, Baik JS \& Lim SK 1999 Type1-turn conformation is important for biological activity of the melanocyte-stimulating hormone analogues. European Journal of Biochemistry 265 430-440.

Matteri RL 2001 Overview of central targets for appetite regulation. Journal of Animal Science 79 E148-E158.

Murphy B, Nunes CN, Ronan JJ, Harper CM, Beall MJ, Hanaway M, Fairhurst AM, Van der Ploeg LH, MacIntyre DE \& Mellin TN 1998 Melanocortin mediated inhibition of feeding behavior in rats. Neuropeptides 32 491-497.

NRC 1998 Nutrient Requirements of Swine. Washington, DC: National Academy Press.

Ollmann MM, Wilson BD, Yang YK, Jerns JA, Gantz I \& Barsh GS 1997 Antagonism of central melanocortin receptors in vitro and in vivo by Agouti-related protein. Science 278 135-138.

Oosterom J, Garner KM, den Dekker WK, Nijenhuis WA, Gispen WH, Burbach JP, Barsh GS \& Adan RA 2001 Common requirements for melanocortin-4 receptor selectivity of structurally unrelated melanocortin agonist and endogenous antagonist, Agouti protein. Journal of Biological Chemistry 276 931-936.
Raposinho PD, Castillo E, d'Alleves V, Broqua P, Pralong FP \& Aubert ML 2000 Chronic blockade of the melanocortin 4 receptor subtype leads to obesity independently of neuropeptide $\mathrm{Y}$ action, with no adverse effects on the gonadotropic and somatotropic axes. Endocrinology 141 4419-4427.

Robbins LS, Nadeau JH, Johoson KR, Kelly MA, Roselli-Rehfussl L, Baack E, Mountjoy KG \& Cone RD 1993 Pigmentation phenotypes of variant extension locus alleles result from point mutations that alter MSH receptor function. Cell 72 827-834.

Rossi M, Kim MS, Morgan DG, Small CJ, Edwards CM, Sunter D, Abusnana S, Goldstone AP, Russell SH, Stanley SA et al. 1998 A C-terminal fragment of Agouti-related protein increases feeding and antagonizes the effect of alpha-melanocyte stimulating hormone in vivo. Endocrinology 139 4428-4431.

SAS 1999 SAS User's Guide (Version 8·1). Cary, NC: Statistical Analysis Systems Institute, Inc.

Schioth HB, Kakizaki Y, Kohsaka A, Suda T \& Watanobe H 2001 Agouti-related peptide prevents steroid-induced luteinizing hormone and prolactin surges in female rats. Neuroreport $\mathbf{1 2}$ 687-690.

Seeley RJ, Yagaloff KA, Fisher SL, Burn P, Thiele TE, van Dijk G, Baskin DG \& Schwartz MW 1997 Melanocortin receptors in leptin effects. Nature 390349.

Shutter YR, Graham M, Kinsey AC, Scully S, Luthy R \& Stark KL 1997 Hypothalamic expression of ART, a novel gene related to agouti, is up-regulated in obese and diabetic mutant mice. Gene and Development 11 593-602.

Skuladottir GV, Jonsson L, Skarphedinsson JO, Mutulis F, Muceniece R, Raina A, Mutule I, Helgason J, Prusus P, Wikberg JE et al. 1999 Long term orexigenic effect of a novel melanocortin 4 receptor selective antagonist. British Journal of Pharmacology 126 27-34.

Tatro JB 1996 Receptor biology of the melanocortins, a family of neuroimmunomodulatory peptides. Neuroimmunomodulation 3 259-284.

Thiele TE, van Dijk G, Yagaloff KA, Fisher SL, Schwartz M, Burns P \& Seeley RJ 1998 Central infusion of melanocortin agonist MTII in rats: assessment of c-Fos expression and taste aversion. American Journal of Physiology 274 R248-R254.

Valverde P, Healy E, Jackson I, Rees JL \& Thody AJ 1995 Variants of the melanocyte-stimulating hormone receptor gene are associated with red hair and fair skin humans. Nature Genetics 11 328-330.

Wantanobe H, Schioth HB, Wikberg JES \& Suda T 1999 The melanocortin 4 receptor mediates leptin stimulation of luteinizing hormone and prolactin surges in steroid-primed ovariectomized rats. Biochemical and Biophysical Research Communications 257 860-864.

Wilson BD, Bagnol D, Kaelin CB, Ollmann MM, Gantz I, Watson SJ \& Barsh GS 1999 Physiological and anatomical circuitry between Agouti-related protein and leptin signaling. Endocrinology 40 2387-2397.

Wirth MM \& Giraudo SQ 2000 Agouti-related protein in the hypothalamic paraventricular nucleus: effect on feeding. Peptides 21 1369-1375.

Wolf GL, Roberts DW \& Galbraith DB 1986 Prenatal determination of obesity, tumor susceptibility and coat color pattern in viable yellow (Av/a) mice. Journal of Heredity 77 151-158.

Received 4 November 2003

Accepted 12 December 2003

Made available online as an

Accepted Preprint 29 December 2003 